\title{
THE HISTORY OF THE THEOLOGICAL
} TERM 'SUBSTANCE': PART III.

IN previous articles we have considered the history of this word 'Substance' in its theological relations, during the time in which pagan philosophy and Christian doctrine were being brought into comparison and contrast. We have observed the way in which associations hidden in the philosophical vocabulary came to be modified, when the Church from the necessity of the case adopted this vocabulary for the accurate expression of its doctrine. We now pass to the consideration of a very different situation. It will be necessary only to note briefly some of the characteristic differences. The previous discussions were concerned with the nature of God as revealed by the Incarnation. Years of controversy had brought this question to something like a determined conclusion. In the subsequent period, therefore, the doctrine of God is taken rather as a datum--a starting-point for exposition, than a matter in debate. Further, in the previous period Greek philosophy, though long past its prime, was still in some sense a living force. We are now concerned with a time when it had ceased even in the country of its birth to be a profitable pursuit, and when the larger problems and the old way of treating them had passed out of the memory of men. For the discussions to which we must now turn arise and are carried on in the West, by people who deal with Greek philosophy in fragments translated into Latin, or filtered through the writing of Augustine or Jerome, or Isidore of Seville. It is true that the latest phase of Neo-platonism finds an enthusiastic support in the work of Scotus Erigena. He translated the writings of the pseudo-Dionysius into Latin, and his own point of view is closely akin to that of this unknown Platonist. But Harnack hardly goes too far when he says of him (Dogmengesch. iii p. 
224 n.), 'Without influence in his own day, and even treated with suspicion, he did not even in later times become a teacher of the West, though western mystics have learnt much from him.' Had this been different, had Scotus attained the position his power and insight deserved, the history of mediaeval systematic philosophy would certainly have been widely different. Erigena made a serious attempt at a philosophic system on the grandest scale. Reason is for him a real instrument for the attainment of truth, and he is prepared to deal somewhat freely with doctrine, to claim, at least, that it must submit to philosophic interpretation, and find its place in a philosophic system. Such a method was entirely alien to the spirit of the age, to which philosophy was rather a process by which truth, otherwise attained, was articulated, than an instrument of attaining it.

It will not fall within our scope to enter at length into the conditions and minuter history of scholastic thought: it will only be necessary to make plain the origin of the scholastic discussions sufficiently to account for the form of the Eucharistic controversy which will be our main subject. We notice first that the gradual collapse of the Greek philosophic impulse had led to the closing of an ancient controversy. In the old days there had been a rivalry between the schools of Plato and Aristotle: it had by no means been admitted that these two philosophers and their followers had been really very close together in their doctrine. But the later forms of Platonism had been very largely influenced by Aristotelian doctrine, and at the end of the career of the School of Plato we find a Platonist like Simplicius commenting on Aristotle and maintaining his essential agreement with Platonic doctrine. Perhaps of all the works attributed to Aristotle we should least expect this assertion to be maintained in regard to the Categories: the ten Categories seem to imply a direct criticism of the Platonic ideal theory. Yet in his Commentary on this work Simplicius warns us not to assert disagreement between the philosophers, $\pi$ pòs rìv

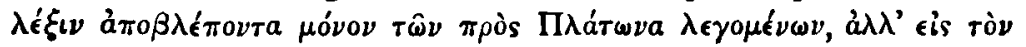

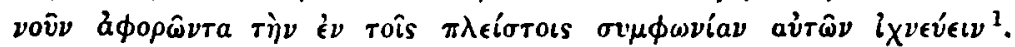
A somewhat similar view is expressed by Boethius, who, though 
mainly Platonist in his sympathies ${ }^{1}$, yet hopes to demonstrate the considerable agreement between the two thinkers ${ }^{2}$.

Such discussion as there was on metaphysical questions at the beginning of the mediaeval period arose in connexion with the interpretation of Aristotle's logical doctrine. It seems clear that the western world was entirely without translations of the larger works of Aristotle till the twelfth century, and the treatises by which he was known were mainly the Categories, and the De Interpretatione, together with Porphyry's Isagoge ${ }^{3}$. Besides these there was a treatise attributed to $S$. Augustine on the Ten Categories which was commonly read: there were the Commentaries of Boethius on the Isagoge, the Categories, and (in two forms) on the De Interpretatione, and the works of Cicero and Seneca. The thinkers of the early Middle Age were thus without the most elaborate and distinctive works of Greek philosophy and evolved their system, in large measure, for themselves.

The starting-point of their enquiry seems to have been a phrase in the Introduction of Porphyry, in which the author raises the question of the nature of universals, and dismisses it as being beyond his scope 4 . On this treatise of Porphyry's, Boethius the Consular wrote two commentaries. One of these is in the form of a dialogue and is based on the current translation of the Isagoge made by Victorinus: the other is a continuous discussion of the whole work based on a translation made by Boethius himself ${ }^{5}$. In both treatises Boethius approaches the question which Por-

'Comm. in Porph. Is. lib. i ad fin.

' Comm. in De Interp. Maior. lib. ii : 'His peractis non equidem contempserim Aristotelis Platonisque sententias in unam quodammodo revocare concordiam, et in his eos non, ut plerıque, dissentire in omnibus, sed in plerisque quae sunt in Philosophia maxıme consentire demonstrem.'

' Cousin, Ouvrages Inédits d'Abélard, p. lii, says flatly (on the strength of a passage in Abel. Anal. Pri. p. 228, ed. Cousin) that Boethius had not translated any of the other books included in the Organon. A translation of the Analytics, Prior and Posterior, of the Topics and of the Sophistic Elenchi is included in his works (ed. Bas. I570) and apparently accepted by Zeller, Gesch. d. grech. Phal Bd. iii 2 p. 858 n. The Analytics were certainly known in Latin by the time of John of Salisbury.

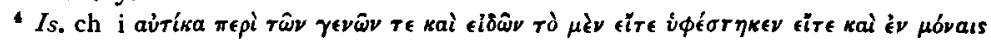

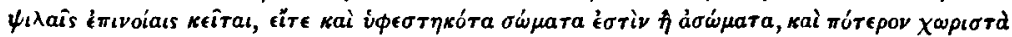

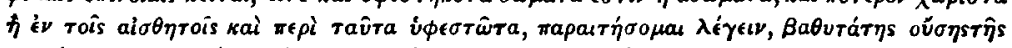

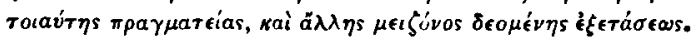

- The two works are so distinguished in the Basle edition, $157^{\circ}$. 
phyry leaves aside: but he arrives at different results. In the first treatise he adopts a conclusion that would be called, in Scholastic language, a realism of the most uncompromising kind : in the other, his solution is more like the view of the nominalists. In the first treatise ${ }^{1}$ the author explains the question raised by Porphyry with some care and then proceeds to deal with it. He makes the question turn on the five predicables, the subject of the Isagoge. These must be real existences, he contends : else the things to which they apply would not exist: ' $\mathrm{Si}$ rerum veritatem atque integritatem perpendas, non est dubium quin vere sint. Nam cum res omnes quae verae sunt, sine his quinque esse non possint, has ipsas quinque res vere intellectas esse non dubites.' The same argument applies to the Categories: 'Cur enim Aristoteles de primis decem sermonibus genera rerum significantibus disputaret? vel eorum differentias propriaque colligeret, et principaliter de accidentibus dissereret, nisi haec in rebus intimata et quodammodo adunata vidisset?' The question of their existence being thus settled Boethius turns to the second point raised by Porphyry, whether they are corporeal or incorporeal; he decides that they are incorporeal. And in answer to the third of Porphyry's questions, in what relation they stand to corporeal existence, concludes that they are sometimes united to it and sometimes not ${ }^{2}$.

In the second treatise Boethius argues in different style. $\mathrm{He}$ contends that a common notion which includes opposites must be equally present in all its constituent species and cannot therefore be really existent: 'Si neque unum est, quoniam commune est, neque multiplex, quoniam eius quoque multitudinis genus aliud inquirendum est, videbitur genus omnino non esse ${ }^{3}$.' $\mathrm{He}$ then shows with great clearness, and by aid of arguments drawn, without acknowledgement, from Aristotle, how the mind by reflexion and abstraction attains these universal ideas: and he points out that, though produced by this action on the part of the mind, they are not false ideas, but means by which the mind can attain real truth. The passage concludes with the following curious statement: 'Plato genera et species caeteraque sensibilia non modo intelligi universalia, verum etiam esse, atque praeter

1 Opp. Boeth. ed. Bas. 1570 , pp. 8 seqq.

2 Op. cit. pp. 9, Io.

Opp. Bueth. p 55. 
corpora subsistere putat: Aristoteles vero intelligi quidem incorporalia atque universalia, sed subsistere in sensibilibus putat, quorum diiudicare sententias aptum esse non duxi, altioris enim est philosophiae. Idcirco vero studiosius Aristotelis sententiam executi sumus, non quod eam maxime probaremus, sed quod hic liber ad predicamenta conscriptus est, quorum Aristoteles auctor est ${ }^{1}$ ' Boethius speaks apparently rather as an exegete than as a philosopher. The effect of his words, however, in this second mood, has been most influential upon those who followed him.

The discussion of this question, uncertain as its result is, still is a revival of a serious problem-that which divided the Platonic and Aristotelian schools: and the account which Boethius gives of the different attitudes of Plato and Aristotle is roughly true. But it was a new thing to raise the question over the Predicables. Porphyry seems to have definitely intended to exclude all metaphysics from his purview and to use the words genus, species, \&c. in a purely logical or even grammatical sense. Moreover, as Cousin pointed out ${ }^{2}$, there is a confusion involved in raising the question here at all : 'Boece ... a converti la grande et légitime question de la réalité des genres et des espèces en la question insensée, et qui n'en fut jamais une, de la réalité du genre, de l'espèce, de la différence, du propre, et de l'accident.' It is possible, no doubt, to exaggerate the influence of this confusion, but it certainly is a confusion and has its effects. The Predicables cease to be a list of Heads of possible affirmations and denials, they acquire a kind of independent value as a scientific principle of reality: the so-called Tree of Porphyry and other formal logical processes take on the appearance of scientific methods. This is true of the Predicables even with the less severely realistic solution of Porphyry's question which Boethius adopts in his second work on the Introduction.

There is, as we now see, a somewhat imperfect clearness in Boethius's treatment of the Predicables : the same quality affects his discussion of the Categories. He announces with considerable decision that the division into the Categories refers only to words ${ }^{3}$ : but, as may be readily understood, he finds a difficulty

1 Op. cit. p. 56

- Ouvrages Inedits d Abelard, Introd. p. Ixvii.

'Opp. p. 127 : ' Non de rebus, sed de vocibus tractaturus est, ut diceret: Dicuntur' 
in maintaining this position firmly. We have two divisions sermonum omnium given and discussed. One, which Boethius calls 'parvissima,' is into four heads : substantia, accidens, universalis, particularis': and he adds 'Omnis enim res aut substantia est, aut accidens, aut universalis, aut particularis.' These four terms are capable of combination, indeed the two substantival terms cannot be expressed except as either universal or particular. Thus man is substantia universalis, Socrates is substantia particularis, scientia is accidens universalis, Grammatica is accidens particularis. In like manner in reference to the Categories Boethius tells us 'Omnis res aut substantia est,' \&c.; and then he adds 'quo circa tot erunt etiam sermones qui ista significent.' What we have, in other words, is not merely a grammatical or logical treatise in which the distinctions of terms could be laid down, but a discussion of terms on the hypothesis that they closely correspond to the differences in things. Some of the distinctions drawn are more completely verbal than others. The general terms colour and white are accidents and not secundae substantiae, because they are not generic or specific names of concrete individuals. This looks more like a distinction between various kinds of general names. But the distinction between substance and accident has a more metaphysical air: 'substantia locus quidem est ubi accidentis valeat natura consistere.' This is a metaphor, no doubt : but it implies an assertion of the validity in nature of the distinction of substance and accident ${ }^{1}$.

The general drift of the philosophy of Boethius is peripatetic in character in spite of the shorter treatise on the Introduction. But he does not seem to us to go very far into the questions before him, or to be fully aware of the very great problems which underlie his discussions. He is not, as we have seen, severely consistent : nor would it be hard to find other evidences of inconsistency. One very conspicuous case occurs in the theological treatise $D e$ Trinitate, if that is really his ${ }^{2}$. In this work the

(referring to the words of the text ' Eorum quae secundum nullam complexionem dicuntur'): 'res enim proprie non dicuntur, sed voces.'

1 Opp. p. 120.

2 The authenticity of the Theological Treatises is doubtful. Haureau, in his Histoire de la Philosophie Scolastique (vol, i pp $45^{\mathrm{I}-2}$ ), repudiates them with scorn: he offers no reasons, however, and describes the books inaccurately. Nitzsch, author of a monograph on the system of Boethus, and of the article on him in

VOL. IV.

D 
author, who, if not Boethius, had the name and weight of Boethius throughout the larger part of the Middle Age, attempts to explain and to vindicate the doctrine of the Three in One. He makes some interesting remarks as to the importance of approaching questions in the method appropriate to the science to which they belong; he discusses the general meaning of number and suggests ways in which triplicity may be consistent with unity: and then proceeds to consider by means of the ten Categories what affirmations are possible about God and in what sense. We are back at once in the atmosphere of neo-platonism. 'Ad aliquid ( $\pi \rho o^{\prime} s \iota$ ) omnino non potest praedicari. Nam substantia in illo non est vere substantia, sed ultra substantias. ... Cum dicimus Deus substantiam quidem significare videmur: sed eam quae sit ultra substantias. Cum vero iustus, qualitatem quidem, sed non accidentem, sed eam quae sit substantia, et ultra substantiam. Neque enim aliud est Deus quod est, et aliud quod iustus est : sed idem est esse Deo quod et iustum '.'

When we remember that the thinkers of the Middle Age started with an extremely limited library and that the Commentaries of Boethius and the theological treatises ascribed to him had a place in it, it will not seem excessive to have spent some time over this author. The main result noticeable is that we have in Boethius words which would necessarily arouse the question between the Nominalists and the Realists, but also suggestions which would lead to both conclusions. It was this controversy which occupied the minds of philosophers most completely during this period, and governed their attitude towards other disputes: and the germ of it all is to be found in Boethius. But besides this, it is important to notice that the questions involved in this controversy are raised and discussed in the region of Logic. This also was largely due to Boethius. It was in many ways unfortunate. The old controversy between the schools of Plato and Aristotle was a question between two different ways of looking at the world. And though this emerged in the later controversy, the discussion was always hampered

Herzog's Real-Encyclopaide, also rejects them. He admits the ancient tradition which ascribes them to him, but thinks their genuineness extremely improbable in view of the number of persons of the name Severinus. Harnack, however (Dogmengeschichte, ii p. $30 \mathrm{n}$.), thinks that Usener has proved their genuineness. According to Nitzsch, one is already cited as Boethius by Alcuin.

1 Opp. p. Ir24. 
in its movement by the forms in which it was conducted; and the absence of any general criticism of principles made it easy to assume that logical forms were also principles of knowledge, and to take commentaries upon authoritative documents as the natural form of philosophical speculation.

There are various problems in Theology which the controversy as to the nature of Universals was bound to affect. The most important relate to the nature of God, and the theory of the Eucharist. We must recall the fact that philosophy stands to doctrine exactly in the opposite relation to that which it held in patristic times. When the Church first began to deal with the question of its own creed, philosophical theories were in possession of educated thought: and the problem was to express accurately with the aid of the precise language of philosophy the doctrinal inheritance of the Church. By the time of the Schoolmen doctrinal discussions were largely settled: the main lines of the Creed were firmly defined, in such a sense that divergence from them was an offence; and the problem for thinkers was to make the surviving fragments of philosophical language express and, in a measure, criticize the dogma defined. Thus we have now to consider the effect of the contact of a clearly formulated Trinitarian doctrine with the new discussion as to Universals.

The first person of whom we must speak is Roscellin. Unfortunately his actual works are no longer extant, but we have evidence of his views in Anselm and Abelard '. From this it will appear that he was a Nominalist of an extreme kind. He seems to have held that general names were merely flatus vocis, and corresponded to no reality ${ }^{2}$ : and Abelard affirms that he made the same assertion in regard to the parts of a body ${ }^{3}$. It was the effect of this view on the Trinitarian doctrine that led to Anselm's attack upon Roscellin. In the work above mentioned Anselm does not discuss the question of Universals; he notes some of the consequences of the theory in the region of philosophy, but is chiefly concerned to trace its heretical results. Philosophically, it

1 Anselm, Liber de Fide Trintatis, chs. i-iii. Abelard Dialectica, P. v. p. 47I, ed. Cousin.

Ans. op, cit. ch. ii.

3 Abel. loc. cit. ' Fuit autem, memini, magistri nostri Roscellini tam insana sententia ut nullam rem partibus constare vellet, sed sicut solis vocibus species ita et partes adscribebat.' 
is Materialism: theologically, it is either Sabellianism or Tritheism, according as those who hold it lay emphasis on the Unity of God, or on the diversity of the Persons to whom Divine attributes are ascribed. The language used by Anselm is noticeable. He says that the philosophers in question 'non nisi flatum vocis putant esse universales substantias, et colorem non aliud queunt intelligere quam corpus, nec sapientiam hominis aliud quam animam.' He says further that these men's mind is so 'imaginationibus corporalibus obvoluta, ut ex eis se non possit evolvere, nec ab ipsis ea, quae ipsa sola et pura contemplari debet, valeat discernere ${ }^{1}$ ' The phrase universalis substantia comes from Boethius, and means, of course, the general terms-universals : the rest of the passage hints at the way in which Anselm thought these universals were reached, viz. by Abstraction; and the power of reason to contemplate them. From the Monologium it is plain that the head of the scheme of universal constitutive ideas was the summa substantia, i.e. God.

Anselm, as we see, rejects Nominalism altogether: for him the general idea is the true reality ${ }^{2}$, and God on the metaphysical side is the supreme reality ${ }^{3}$. Abelard also regards God as summa substantia: but his different theory of existence involves a different application of the word to Trinitarian theology. Abelard was equally discontented with both schools of philosophy. He rejected the doctrine of Roscellin, and also claims to have publicly disproved that of William of Champeaux (who professed an extreme form of Realism) and compelled him to modify his teaching. This attitude makes it difficult to say precisely what his own doctrine was. A few things are certain. Abelard started from the individual person or thing, just as Roscellin had done; but he gave more reality and significance to the higher and more general ideas than he. Also, he attributed the formation of these ideas to the operation of the mind. 'Speciem igitur dico esse non illam essentiam hominis solum quae est in Socrate, vel quae est in aliquo alio individuorum, sed totam illam collectionem ex singulis aliis huius naturae coniunctam $\because$ ' This rather obscure sentence

1 Op. c1t. ch. ii ad fin.

Monol. ch. i.

s 'Summa substantı' Monol. ch. xi ; 'Essentia' ch. xil ; ' natura' ch. xill. Cf. De Fude Trn. ch. $1 \mathrm{x}$.

- Omvrages Inédits, ed. Cous.; Dial. P. v. p. 524 . 
seems to be intended to protect the theory from any suggestion of the separateness of universals : it is in them, different in each and yet similar: and the whole collection of these individual essences makes the species, 'just as a people is called one, though it is formed by the combination of many persons.' The general element Abelard calls the matter, the individualizing element he calls form. Applying this process to wider and wider class-names we reach at last the ultimate substance 'quae tamen nondum est simplex, sed ex materia mera essentia, ut ita dicam, et susceptibilitate contrariorum forma constat ${ }^{1}$.' Thus it would seem that Abelard, starting with the intention of recognizing the truth in both Schools, never really overcomes the opposition between the individual and the universal. The relation of form and matter by which he interprets it pursues him to the end.

When we ask how the notion of Substance is applied to God we find that the theological requirements of the case involve some modification. Abelard states and reiterates that God is substantia, and as such is absolutely simple, this being assumed to be a superior type of reality to anything in which there is multiplicity. But he has to reconcile this with the doctrine of the Trinity. In his interpretation of this he uses, of course, the orthodox names of the Three Persons, but he gives them a kind of abstract interpretation. The Father is equivalent to Power, the Son to Wisdom, the Holy Ghost to Benignity ${ }^{2}$. There he treats this diversity in the Unity of God as a diversitas proprietatum, and is careful to state that it involves no breach of unity in substance. - Constat... quoque nullam trium personarum ab alia substantialiter esse diversam, vel etiam secundum numerum rerum esse discretam, sed tantummodo proprietate sua diversam esse unam ab alia, non autem substantia dissimilem aut numero, ut Arius putat.' He argues that human individuals do not differ in substance : still less is there any final difference between one Person in the Holy Trinity and another-'quarum unica est penitus substantia singularis, nullam partium aut formarum diversitatem recipiens 4.' Two questions arise out of this view which are relevant to our present purpose : (I) What is the relation between

1 Op. cit. pp. $5^{2} 5^{-6}$.

2 Opp. Abael. ed. Cous. Theol. Christ. I c. ii p. 360.

3 Theol. Christ. III p. 468. 
the substance and the properties? (2) Why is the number limited to Three? Abelard denies that the diverse properties which constitute the diversity of Person inhere accidentally in the Divine substance. They are substantialiter inhaerentes. 'Omnino enim Deum necesse est esse sapientem, nec ullo modo aut non esse potest, aut non esse sapiens, aut aliquam suscipere corruptionem, ut ei aliquid accidere possit '.' This view he connects with the transcendent notion of Boethius that the Divine substance is ultra substantiam ${ }^{2}$. But though he rejects the phraseology of substance and accident, and even of matter and form ${ }^{3}$, he uses the analogy of wax and the image made of wax to illustrate the relation between the Father and the Son. 'Est divina Sapientia ex divina Potentia: quomodo cerea imago est ex cera, aut quomodo, iuxta philosophos, species ipsa ex genere esse dicitur cum tamen idem sit species quod genus, ut homo idem quod animal et imago cerea idem quod cera 4.' This process he conceives as being timeless, as also the Procession of the Holy Ghost. In answer to the question why the number of these properties should be limited to Three, he answers bluntly that the authority of the Church has so limited them ${ }^{5}$.

When Abelard affirms that the ultimate Substance is God, or uses the word substantia as the fittest to describe Him, we seem to be on familiar ground. But the question whether the proprietates inhere substantialiter or accidenter is not one which would have occurred to a real Platonist or Aristotelian. It comes from the narrower logical associations into which the conditions of mediaeval thinking had brought these discussions. In Plotinus and the theologians who were most profoundly affected by neo-

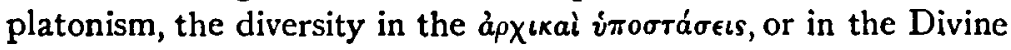
substance, was a necessary and timeless process. There are reminiscences of this position in Abelard, as when he says that the generative process is beyond time, and in the discussion earlier in the Theologia Christiana of the relation of the two terms Verbum and Sapientia. But the contrast between substance and accident haunts the word, and while it complicates the conception of the relation of the substance and the properties it further involves the theologian in the difficulty of saying what

1 Op. cit. p 47 r.

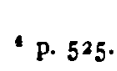

s. $47^{2}$.

s p. 496. 
are and what are not essential attributes. In the earlier stages of thought it might have been hard to say how the generation of the Son was to be distinguished from the creation of the world, but Abelard's difficulty could not have arisen because the conception of substance was different. The association of the word before had been with just those parts of Greek philosophy of which the direct knowledge had so largely disappeared: with the Schoolmen the notion of substance was associated with the logical use of it, modified by some imperfect glimpses of the wider point of view.

It is worth noticing that this difficulty which arose, as we venture to think, from the logical associations of the word Substantia, seems to have affected scholastic thought even after the deeper study of Greek philosophy had again become possible. The question of the Attributes of God, and how to interpret them in connexion with the Divine Substance and the Trinity of Persons, is a question which belongs to the scholastic theory of substance. We have seen that Abelard found it by no means free from difficulties. Successors of his were no less perplexed. For the theory which was associated with the distinction of substance and accident was always in danger of a form of Sabellianism and of holding to the existence of a single undifferentiated Divine substance to which attributes became attached in a more or less accidental way : so that the Personal distinctions themselves were in danger of being treated as accidental. This is the meaning attached to the theory of Gilbert de la Porrée-a later contemporary of Abelard's-that the Trinity cannot be predicated of God substantialiter ${ }^{1}$. But even later still St. Thomas Aquinas, though he has accepted the negative conception of the Being of God which dates back to neo-platonism, endeavours to explain the position of the Attributes. God is not adequately or necessarily known by us: 'essentia eius est supra id quod de Deo intelligimus et voce significamus 2.' We use names of God, and it is not quite true to say that they have only a negative meaning: 'et ideo dicendum est quod huiusmodi nomina significant substantiam divinam et praedicantur de Deo substantialiter : sed deficiunt a repraesenta-

1 Cf. Baur, Lehre von d. Dreneingkent, vol. ii p. 511 \&c.

2 Summa Theol. P. I. qu. xili art. 1 ad primum; cf. art. 2. 
tione ipsius'.' God has eminentiori modo all the perfections which there are, and of which we observe imperfect copies in nature. So far there is little talk of accidents and substance. But in a later section when he comes to discuss the multiplicity in the Godhead and therefore the presence of relativity within its unity he deals with the question in connexion with the Categories and condemns Gilbert de la Porrée, not for bringing in considerations from an inappropriate region of philosophy, but for using them wrongly ${ }^{2}$.

We have mentioned this controversy, though it lies somewhat outside the main subject, because it emphasizes the persistence with which the notion of substance and accident in its logical shape affected mediaeval thought. This is, perhaps, in no way an unexpected or startling announcement: it is, however, of great importance to keep it firmly before us in discussing the next subject which comes before us, the application of the notion of substance to the Eucharist. In order to explain this point clearly it will be necessary to go back in the history a short way and indicate the stage of the discussion upon this Sacrament.

The history may be said to begin with Paschasius Radbert, who was abbot of Corbey, and died in or about 85I. His treatise De Corpore et Sanguine Christi, which belongs to the year $83 \mathrm{I}$, is the first work devoted entirely to the subject ${ }^{3}$, and we may therefore well begin with some account of its doctrine. He treats the effect of consecration as a miracle, on the analogy of the Incarnation itself (c. iii): as that was the effect of the operation of the Holy Spirit, so 'per eundem (Spiritum) ex substantia panis ac vini mystice idem Christi corpus et sanguis consecratur' (c. iv). Further, though it is true to speak of the outward part of the Sacrament as figura, yet this does not exclude the reality of that which it conveys: the true Body and Blood are there by a miraculous process, which Paschasius definitely declines to attempt to explain (c. iii 3). The wicked,

1 Op. cit. qu. xiii art. 2.

2 Summa Theol. P. I. qu. xxvini art. 2. For the further history of this discussion see Baur as above; Werner, Die nach-scotistische Scholastik, ch. 7 .

3 Harnack, Dogmengesch. ill p. $27^{8}$. 
though they receive the true Body and Blood, derive only judgement from the reception of it : as is shown by certain miraculous occurrences which have befallen unworthy recipients (c. vi). And further, so great is the change consequent on the words of consecration that the elements can only be called Bread and Wine in a spiritual sense. The Bread is still bread, "quia Christi caro et vera caro, et tamen panis vivus qui de caelo descendit iure catholice praedicatur. . . . Secundam praemissam doctrinae veritatem nihil aliud quam caro Christi et sanguis iure creditur, quae non sapore carnis, sed spiritali dulcedine degustantur, et fidei ratione intelliguntur' (c. xvi). This view seems to exclude the doctrine of a Presence real only to the faithful recipient, and, except that it provides no explanation of the miracle, it closely resembles the later articulate doctrine. Those who go back to Paschasius for the doctrine of Transubstantiation are justified in so doing, though the word is never mentioned in his treatise, and though there is comparatively little said about substantia at all 1. It is clear that the real question depends on the result of the words of consecration; when these are pronounced, do the bread and wine remain any longer in existence or do they disappear altogether, their place being taken by the Body and the Blood? Paschasius seems to have assumed the second of these alternatives, and his view was probably the prevalent one. In the eleventh century the controversy between Berengarius and Lanfranc mainly turns on this point. The terminology which the opponents used is not very precise: there is not as yet any direct use of the contrast of substantia and accidens. But the discussion points to the solution which the use of this contrast supplies. The word substantia occurs with some frequency in both authors, and in the documents connected with the controversy. Berengarius is made to accept the view 'panem et vinum quae in altari ponuntur post consecrationem non solum sacramentum sed etiam verum corpus et sanguinem Domini nostri Iesu Christi esse, et sensualiter non solum sacramento

1 The question of the reception of the wicked is not in so many words before Paschasius. He discusses and endeavours to define the judgement with which St. Paul threatens them : and so tells stories of miraculous paralysis or other misfortunes which have befallen the unworthy. From this, we should infer that the judgement consisted not in missing reception of the Body altogether, but in incurring punıshment for sacrilegiously approaching so holy a Thing. 
sed in veritate manibus sacerdotum tractari' : and again, 'panem et vinum substantialiter converti . . . non tantum per signum et virtutem sacramenti, sed in proprietate naturae et veritate substantiae '.' For the word substantia Berengarius occasionally uses subiectum ${ }^{2}$. He speaks of the theory which he disapproves as explaining the effect of consecration per generationem subiecti (carnis) $^{3}$ : he claims that Ambrose supports him in holding that the elements remain secundum proprietatem speciei suae: and he explains the phrase as follows: 'speciem autem dico secundum subiecta ipsa panem et vinum, non secundum colorem vel quae in subiectis eis sunt accidentia "'

In the phrase last quoted the formula of Transubstantiation is almost fully expressed. The word seems to occur first somewhat later at the beginning of the twelfth century ${ }^{5}$, but there is little further development wanted to articulate the idea. It will not be necessary to trace the doctrine through all its phases: for our present purpose it is sufficient to have established the associations of the phrases when they appear. We pass on, therefore, to consider the elaborate treatment of the whole matter by S. Thomas Aquinas. It is clear that the solution of the difficulty supplied by the doctrine in question is apparent rather than real. When once it has been agreed that the substance of the elements disappears at consecration, it becomes important to explain the phenomena which meet the senses. From the time of Boethius it had been an axiom that the distinction of substance and accident was final: that by substance was meant the reality, which, to use the technical phrase, inhered in no subject, did not require the support of any subject or substance to retain it in being. Accidents, on the other hand, meant those qualities, relations, \&c. which had no independent being, and simply characterized the substance in which they inhered. It was no doubt natural that, when the question of the effect of consecration was raised, this view of reality should be applied to protect and to limit the actuality of the presence of the Lord in the Sacrament : and when thought began to move in these lines, it is difficult to see how the substance of the clements can have

1 Lanfranc, De Corp. Chrasth, c. 2.

- Bereng. de Sacra Coena, ed. Vischer, p. 33 . ' p. Iзo.

- Op. cit. p. 126.

Harnack, Dogmengesch. iii. 338 n. 
been allowed to persist through the change; because the presence of one substance must have seemed inevitably to mean the absence of another ${ }^{1}$. But it could not fail to catch the attention of so exhaustive a thinker as $\mathrm{S}$. Thomas that the accidents which remained preserved a great deal of the force and operation of a substance. It is clear from his language that the matter was in debate, and that various opinions were put forward and discussed. The interest of a largc number of his Quaestiones is to go as far in allowing substantial features to the accidents without exactly confusing them with substances. He argues that the Body of Christ is present 'secundum modum substantiae' and not 'in loco' 2 . On the other hand, the senses report effects from the elements which are indistinguishable from the realities themselves. They inhere in the "quantitas dimensiva sicut in subiecto' 3 . They produce ordinary physical effects-are capable of various physical processes, such as change, corruption, mixture, and there is no sign of the return of the substance of the bread and wine after consecration 4 . The point above mentioned of the accidents inhering in quantitas dimensiva is of special interest. A substance, according to $\mathrm{S}$. Thomas, is a remote reality in which accidents inhere on a quasi-hierarchical principle. 'Quia primum subiectum est materia, consequens est quod omnia alia accidentia referantur ad subiectum, mediante quantitate dimensiva, sicut et primum subiectum coloris dicitur esse superficies.' Hence when the subject or substantia is removed, it follows that by the same miraculous act the quantitas dimensiva is endowed with the power of sustaining all the other phenomena. It is, however, expressly provided that the accidents remain accidents still ${ }^{5}$. It will be seen how difficult a position this really involves. The substance is conceived in sharp opposition to the accidents, yet all the appearances ordinarily attached to the presence of a substance are obviously sustained: the climax is, perhaps, reached in the discussion ${ }^{6}$ as to the possibility of the mixture of some

1 It appears, therefore, to be futile to endeavour to maintain that the Lateran Council of 1215 did not propose to lay the philosophical theory of the Sacrament as a dogma upon the Church. The language they used can hardly have meant anything else.

2 Summa Theol. P. iii Q. lxxvi art v.

- Ib. Q. Ixxuri art. 5 .

Ib. Q. Ixxvii art. 2.

- Ib. Q. Ixxvii art. 8.

Ib. Q. Ixxvii art. $I$ and 2. 
other fluid with the consecrated wine. If so much of the new fluid is added that the character of the wine changes, its sacramental burden will also disappear: 'si fiat tanta permixtio liquoris cuiuscumque quod pertingat ad totum vinum consecratum, et fiat permixtum, erit aliud numero, et non remanebit ibi sanguis Christi.' At this point the distinction of the substance and the accidents ceases to hold, or at least becomes a very precarious instrument of explanation.

The subsequent history of this doctrine before the Reformation is the history of the attempt to make the idea of substance and accidents work intelligibly in regard to the Sacrament. Duns Scotus refines upon the idea of Transubstantiation: the process, he says, is of two kinds, production and adduction. By the former a substance accipit esse as a result of the change: by the latter it only accipit esse lic. And he describes the Sacramental change as being of the latter sort: 'nec panis convertitur nec transit in corpus Christi, nisi secundum esse hic praesens pani praeexistenti 1.' This involves a considerable weakening of the idea of the change, more especially as he further denies any necessity for the annihilation of the substance of the bread. On the other hand, the accidents tend more and more to play the part of a substance. Scotus will not accept the doctrine that on the disappearance of a substance, the accidents require a subject in which to inhere ${ }^{2}$. Inherence is not of the essence e.g. of albedo: though albedo has a tendency to inhere in a subject. And again on the destruction of the elements the Sacrament disappears because God has attached the eucharistic gift to certain qualitative phenomena. The question of the accidentsespecially of the relation of quantity and quality to substancewas still further elaborated by Occam ${ }^{3}$, and it became difficult to be certain what was the distinctive and essential feature of the sacramental element : until $\mathrm{Wyclif}^{4}$ derides the uncertainty prevailing upon the whole subject. The larger part of the province of Canterbury thinks 'quod sacramentum altaris est ponderositas': in the diocese of Lincoln the opinion prevails 'quod hostia altaris est quantitas': others think that it is

1 Sent. iv. dist. $x$.

2 Ib. dist. I 2.

- De Sacr. Altaris, cr. xiv seqq.

- De Euch., Wyclif Socjety's Edition, pp. 183-5. 
qualitas, and of all possible qualities albedo; this view, says Wyclif, prevails in Wales and Ireland 'ubi vident mortuos.'

The purport of these remarkable speculations seems to be, as we have already said, to make the conception of substance and accident work intelligibly in connexion with the Eucharist. And it is hardly too much to say that they make conspicuous the total inadequacy of those Categories for the purpose. The doctrine of Transubstantiation as at first formulated provided what appeared to be a solution of a dogmatic difficulty. There were, on one side, the Lord's words of Institution, and on the other the patent empirical facts : a secret miraculous change that left the accidents unaltered seemed to meet the difficulty. And it was natural to look in this direction for a solution, because of the prevailing tone of philosophical thought, and because it seemed axiomatic that two realities (or substantiae) could not occupy the same space ${ }^{1}$. But the attempted solution was really a surrender of the doctrinal interest to a philosophical theory, which was quite incapable of doing the work required of it. And the successive refinements upon the words substance and accident lead us no further philosophically, nor get rid of the inexorable contrast between the two categories, nor seriously help to the understanding of the Sacrament. They are only a means of retaining the formula of Transubstantiation, at the expense of its meaning.

T. B. Strong.

1 Occam rejects this principle, following Scotus, on the ground that it limits the Divine Omnipotence; De Sacr. c. v. 